\title{
The 2018 US-Korea FTA Revision: From the US Perspective
}

\author{
Binwu Qin* \& Rajesh Sharma**
}

The US-Korea FTA, in its initial days of negotiation saw severe protests by public and political turmoil in Seoul. After crossing several procedural hoops and political hurdles in parliaments of both countries it became effective in 2012, though it was signed in 2007. At that time, it was considered by the US a 'model agreement' which could open opportunities for the US exporters in the Korean market. However, only couple of years later, the Trump administration called this FTA a horrible' deal that has 'destroyed' America. Thus, the Trump administration wanted to scrap the FTA. After considering the political implications of such action, the US government decided to re-negotiate the FTA so that the US concerns are addressed. In a short period of negotiation, both sides agreed to the revised terms of the FTA which has become effective from January 1 , 2019. This paper analyses outcomes of the revised US-Korea FTA, 2018 from the US perspective and evaluate if all concerns of the US are met.

\section{Keywords}

US-Korea FTA, KORUS, Truck Tariffs, Automobile Exports in Korea, ISDS, Customs Principles, Pharmaceutical Reimbursements

* Associate Professor at Xiangtan University Law School, Xiangtan, P.R. China; Research Staff of Collaborative Innovation Center for Rule of Law in Hunan and Governance of Regional Society. LL.B. (Lanzhou Univ. of Fin. \& Econ.), LL.M (Xiangtan Univ.), J.D. (St. Thomas Univ.). ORCID: https://orcid.org/0000-0001-9049-7441. The author may be contacted at: 1877992620@qq.com/Address: \#304, Law School Building of Xiangtan University, Xiangtan, Hunan Province 411105, P.R. China.

** Senior Lecturer at Criminology \& Justice Dept. of RMIT University, Melbourne, Australia; Honorary Professor of Xiangtan University, China. LL.B. (Dehli Univ.), M.Phil. (CUHK), MBL (Monash), Ph.D. (CUPL). ORCID: https:// orcid.org/0000-0002-7564-9141. The author would like to thank Ena Shaw for reading drafts of this paper and giving her constructive feedbacks. The author may be contacted at: Rajesh.Sharma@rmit.edu.au/Address: 411 Swanston Street, Melbourne-3000, VIC, Australia. 


\section{Introduction}

The revised US-Korea FTA ("KORUS FTA") became effective from January 1, 2019. Both the US and the Republic of Korea (Korea) governments have called the revision of KORUS FTA as a win-win for them. ${ }^{1}$ According to the US, the original agreement was 'horrible,' but after revision of KORUS-FTA has become balanced. ${ }^{2}$ For Korea, this revised FTA has facilitated exemption from tariffs on steel by the US, an understanding on currency exchange manipulation and on a more political perspective which paved the way for the peace process on the Korean peninsula. Moreover, as compared to the original KORUS FTA, during the revision of KORUS FTA, domestically there were no severe protests in Seoul.

The United States Trade Representative ("USTR") has announced the following as outcomes of the revised KORUS FTA: 1. The US Truck Tariffs; 2. Growing the US auto exports to Korea; 3. Customs Improvement; 4. Pharmaceutical reimbursements; and 5. Improvements in ISDS. ${ }^{3}$ This paper will analyze each of those outcomes in turn.

\section{The US Truck Tariffs}

The US imposes a 25 percent tariff on the Korean made pickup trucks. As per the original KORUS FTA this tariff was scheduled to end by 2021. However, under the revised KORUS FTA, the US is able to extend this tariff for another 20 years. ${ }^{4}$ This was mainly agreed to keep away the Korean auto makers from entering into the lucrative pickup truck market in the US. With the continued imposition of tariff, it will be hard for the Korean automakers to compete with the US pickup trucks automakers such

1 Moon says revised KORUS FTA will benefit both countries, YonHap News, Apr. 2, 2018, available at https://www. bilaterals.org/?moon-says-revised-korus-fta-will (last visited on Mar. 31, 2019).

2 A. Campbell, Trump's New Trade Deal with South Korea, Explained- The Trade Agreement with Seoul is Supposed to Boost US Car Sales. That's Unlikely, Vox. Sept. 25, 2018, available at https://www.vox.com/2018/9/24/17883506/ trump-korea-trade-deal-korus (last visited on Mar. 31, 2019).

3 USTR, USTR Publishes Agreed Outcomes from US-Korea FTA Amendment and Modification Negotiations, Sept. 3, 2018, available at https://ustr.gov/about-us/policy-offices/press-office/press-releases/2018/september/ustr-publishesagreed-outcomes-us (last visited on Mar. 31, 2019).

4 USTR, New US Trade Policy and National Security Outcomes with Korea (Mar. 2018), available at https://ustr.gov/ about-us/policy-offices/press-office/fact-sheets/2018/march/new-us-trade-policy-and-national (last visited on Mar. 31, 2019). 
as Ford, General Motors and Chrysler. In 2018, Americans bought 17 million vehicles out of which 67 percent were pickup trucks and SUVs. Ford sold 909,330 whilst Chevrolet sold 585, 581 pickup trucks in 2018 alone. ${ }^{5}$ The continued tariffs on the pickup trucks will certainly ruin the plan of Hyundai to launch its pickup truck 'Santa Cruz' in 2021. ${ }^{6}$ Therefore, the revision in this regard in KORUS FTA is more beneficial for the US as compared to Korea.

\section{Growing the US Auto Exports to Korea}

The revised KORUS FTA has ensured more exports of the US automobiles to Korea by increasing the number of auto exports by each American auto manufacturer from 25,000 to 50,000 per year. ${ }^{7}$ Moreover, now the US automobiles do not have to comply with the Korean Motor Vehicle Safety Standards ("KMVSS"). Rather, complying with the US Federal Motor Vehicle Safety Standards ("FMVSS") will be sufficient. As long as the US manufacturer exports 50,000 or less vehicles in Korea, it is deemed to comply with KMVSS if that manufacturer certifies that the motor vehicle is compliant to FMVSS. 8

Therefore, no further modifications in the US automobiles will be currently required to enter into the Korean market. Earlier, the US gasoline automobiles were required to go through duplicative or further testing as per the Korean emission standards. Today, however, the same tests can be done following the US standards in lieu of the Korean emission tests. In this regard, Korea has agreed that Californian methodology is consistent with the US Federal regulations. ${ }^{9}$

Therefore, Korea will amend its relevant regulations for testing procedures and methodology for gasoline-powered motor vehicles such that the tests a manufacturer

5 G. Gastelu, The 10 Best-selling Vehicles in the United States in 2018 were mostly Trucks and SUVS, Fox News, Jan, 4, 2019, available at https://www.foxnews.com/auto/the-10-best-selling-vehicles-in-the-united-states-in-2018-weremostly-trucks-and-suvs (last visited on Mar. 5, 2019).

6 A. Padenau, 2021 Hyundai Santa Cruz Render Proposes Stylish Pickup Truck, Motor1.Com (Mar. 22, 2019), available at https://www.motor1.com/news/314780/2021-hyundai-santa-cruz-render (last visited on Apr. 2, 2019).

7 Supra note 4.

8 Protocol Between The Government of The Republic of Korea and The Government of The United States of America Amending The February 10, 2011 Exchange of Letters, § B (1) (Sept. 3, 2018), available at https://ustr.gov/sites/ default/files/files/Press/Releases/KORUS\%20Texts\%20Outcomes.pdf (last visited on Mar. 31, 2019).

9 Interpretation by The Joint Committee of The Free Trade Agreement Between The Republic of Korea and The United States of America regarding The June 30, 2007 Exchange of Letters, Sept. 3, 2019, available at https://ustr.gov/sites/ default/files/files/Press/Releases/KORUS\%20Texts\%20Outcomes.pdf (last visited on Mar. 31, 2019). 
must conduct for and the test results it must submit to, the relevant US agencies to demonstrate compliance with the US Federal emissions regulations are sufficient to meet Korea's requirements without additional or duplicative testing. ${ }^{10}$ The harmonized testing requirements will certainly reduce the cost of double testing and most importantly bring down the technical barriers to trade between the US and Korea. Though this helps the US automakers in getting a direct market in Korea, this does not prevent Korea to apply its Automobile Management Act as amended with respect to post-market verification and associated regulations relating to witnessing of tests, comments on the results of the compliance investigations and to verify the compliance of the vehicle with FMVSS. ${ }^{11}$

This is significant because the record of the US car companies with regards to emission certificates has not been spotless. In the past years, all major US car companies including Fiat Chrysler and Daimler have been fined for wrong emission certification. Very recently, Ford is under criminal investigation by the US Justice Department for its emission certification process. ${ }^{12}$ That in itself does not prove that the Korean auto companies are following high standards and that their practices are not questionable. For example, both Hyundai and KIA have been fined civil penalty of USD 100 million in 2014 for selling 1.2 million vehicles with inflated fuel economy ratings. ${ }^{13}$

Even the motor vehicle replacement parts originating from the US is deemed to comply with the KMVSS if those parts are compliant with the FMVSS and to be used in vehicles originally imported from the US. In a situation where a certain motor part is not covered under the FMVSS but it is regulated under the KMVSS, then it is still possible for that motor part from the US to be qualified to be used in Korea. As per the revised KORUS FTA, as long as that replacement auto part meets the same or exceeds the standard and performance of the original auto part installed on the vehicle initially imported in Korea, it will be considered in compliance with the KMVSS. ${ }^{14}$

With regards to import of the US manufactured automobiles, Korea retained an emergency power in the revised KORUS FTA. If imported vehicles or vehicle parts cause any risk of road safety, human health or the environment, Korea may take measures necessary to address those risks. However, before Korea takes such

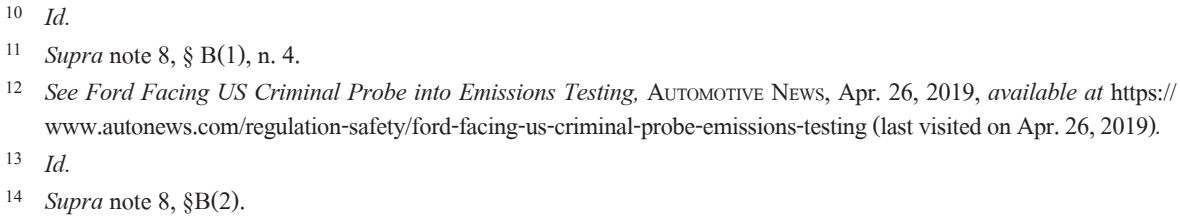


measures, it has to make sure that those risks are supported by scientific and technical information and such measures must not be applied arbitrarily, unjustifiably or discriminatory or as a disguised restriction on trade. ${ }^{15}$ Before Korea takes any such temporary emergency measures, the revised KORUS FTA requires Korea to notify the US and the importer and to provide an objective, and sufficiently detailed explanation of the motivation of the measure including reasons for such decision. In most cases, Korea is also obligated to accord reasonable opportunity to the US and interested persons to give comments on the emergency measure taken by Korea. ${ }^{16}$

Considering the rapid development in automobile sector, the revised KORUS FTA has also taken care of those situations and provided that neither Korea nor the US prevent or unduly delay the entry of a motor vehicle product on the ground that the product incorporates a new technology or a new feature which has not yet been regulated. The only situation this applies is when these new technologies or new features can cause a risk for human health, safety or the environment based on scientific and technical information. Then a motor vehicle product may be prevented or delayed or withdrawn from market. As a balancing act, the Party taking such measures must inform the other Party and the importer about its decisions related to that motor vehicle product which incorporates the new technology or a new feature with full scientific and technical information used in reaching such a decision. ${ }^{17}$

Korea has also promised to revise its regulations, "the Public Notice on Corporate Average Fuel Efficiency Standards and Greenhouse Gas Standards for Motor Vehicles, and Their Application and Management""18 (CAFE Standards) to increase the current cap of total available eco-innovation credit system at the average level of the manufacturer's fleet to $17.9 \mathrm{~g} / \mathrm{km}$. ${ }^{19}$ This expansion of Korea's eco-credit system will help the US vehicles to obtain more market access. Moreover, when Korea establishes its target for 2021-2025, it will pay attention to global trends including the mid-term review results for the US 2022-2025 CAFE regulations. ${ }^{20}$ At the same time, Korea pledges to maintain leniency for small volume manufacturers under the regulations. ${ }^{21}$

There is no doubt that the revised KORUS FTA has created favorable conditions for exporting the US manufactured automobiles and parts to Korea. However, it is

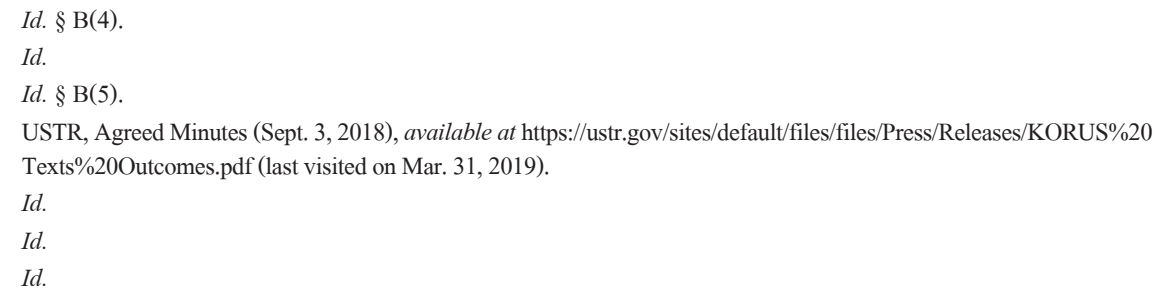


yet to be seen how the US manufactures could realize these benefits. Even during the operation of the original KORUS FTA, the US manufacturers could not export up to their quota of 25,000 vehicles per year to Korea. For example, in 2016, Ford only sold 10,727 cars and Fiat Chrysler could only export 7,284 cars. In the same year, Americans imported the Korean cars worth USD 16 billion as compared to the Koreans imported the US made cars worth USD 1.6 billion. ${ }^{22}$ This may have been seen by the Trump administration as an example to justify original KORUS FTA as 'horrible' deal which 'destroyed' America, but critics suggest it is simply a preferred taste of consumers. ${ }^{23}$ Americans prefer Hyundai and KIA cars, while unfortunately the Koreans do not like Ford, Daimler, Fiat or Chrysler. ${ }^{24}$

\section{New Customs Principles to Verify Origin of Goods}

The US exporters to Korea have been voicing their concerns about onerous and costly customs procedures to verify origin of goods to customs of Korea. ${ }^{25}$ They even complained about inconsistent application of rules, rejection of certification due to minor errors and limitation on corrections. ${ }^{26}$ In order to address these concerns, the US and Korea reached new Customs Principles. These new principles reaffirm the 'knowledge based' self-certification system, which essentially relies on importer knowledge or a certification of origin provided by an importer, exporter, or producer to make claim of preferential tariff. ${ }^{27}$ An exporter or producer is allowed to complete a certification of origin regardless of its residential location of address. If there are any minor errors or discrepancies in any documents such as certification, questionnaire, or other documents, an importer, exporter or producer is allowed to make corrections. In those situations, five working days are granted to resubmit corrected relevant

22 Supra note 2.

23 Id. According to Simon Lester of Cato Institute, American automakers "don't make car that are popular there [in Korea]."

24 Id.

25 Supra note 4.

26 J. Schott \& Euijin Jung, KORUS Amendments: Minor Adjustments Fixed What Trump Called "Horrible Trade Deal," PIIE website (Nov. 2018), available at https://piie.com/system/files/documents/pb18-22.pdf (last visited Mar. 31, 2019).

27 USTR, Customs Principles under the Free Trade Agreement between the United States of America and the Republic of Korea (Mar. 2018), available at https://ustr.gov/about-us/policy-offices/press-office/fact-sheets/2018/march/new-ustrade-policy-and-national (last visited Mar. 31, 2019). 
documents. ${ }^{28}$ This change will bring relief to importers, exporters and producers because earlier for any minor errors or discrepancies the documents were rejected by the Customs of Korea.

For verification of origin, Customs Principles ensures that it is conducted by the importing party through information requests to the importer, exporter or producer. Moreover, it is reaffirmed in the Customs Principles that verification of origin will be conducted only if the customs authority has doubts as to good's originating status. While requesting information to verify origins, the goods under verification must be clearly specified and the information so requested must be for the purpose of determining the origin of the specific goods only. Verification of origin must be processed as expeditiously as possible and no later than 90 days after receiving the information requested by Customs; or counting from the initiation of verification, within a total of a twelve-month period, the process of verification should be concluded. Only in a very exceptional circumstances any extensions of time may be allowed. ${ }^{29}$

The Customs Principles have provided for a process of advance rulings. An importer, exporter or producer may request customs authorities in writing whether a good satisfies the origin requirement. Such advance rulings must only be given in writing and verbal advice is not acceptable under the Customs Principles. ${ }^{30}$

A new sub-committee, the Rules of Origin Verification Working Group under the Committee on Trade in Goods, has been established under the revised KORUS FTA to facilitate overall implementation of verification of origin. One of the purposes of this Working Group is to resolve concerns that arise from matters related to verification of claims of origin. ${ }^{31}$

\section{Pharmaceuticals Reimbursements}

As the Korean pharmaceutical pricing was ill reputed, the US Pharmaceutical Research and Manufacturers of America ("PhARMA") was complaining about lack of transparency, due process and discrimination in fixing prices and reimbursement

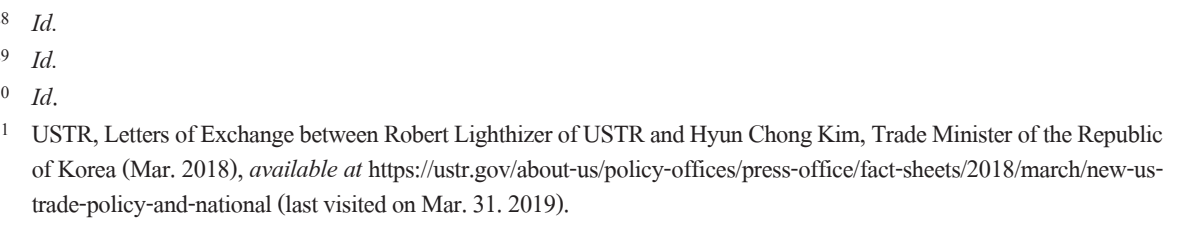
of Korea (Mar. 2018), available at https:/ustr.gov/about-us/policy-offices/press-office/fact-sheets/2018/march/new-ustrade-policy-and-national (last visited on Mar. 31. 2019). 
for biopharmaceutical products. ${ }^{32}$ During the revision of KORUS FTA, the Premium Pricing Policy for Global Innovative New Drugs (Policy) of Korea was on target as it discriminates between the Korean pharma products and the US pharma products. ${ }^{33}$

In Korea, the National Health Insurance Service ("NHIS") has the authority to fix the price of drugs in the Korean market. When pricing foreign drugs NHIS takes weight average of other drugs in their therapeutic class in seven reference countries and applies the lowest possible price domestically. If the sales of that drug increases more than the expected target, then the price is slashed further by 10 percent. Once the generic version the drug is launched on the Korean market, the price of foreign drug naturally falls further. When a domestic drug manufacturer launches a new drug then the NHIS sets the price 10 percent higher with a view to encouraging local manufacturer to come up with new drugs. There is no such scheme of 10 percent reimbursement for foreign pharmaceutical manufacturers unless the foreign company is willing to release the drug first in the Korean market. ${ }^{34}$

During the negotiation for the revision of KORUS FTA, Korea agreed to look into this Policy and if there is a need, it will revise the Policy. The Trade Minister of Korea was upfront in accepting that: "It's necessary to correct wrongs if we find a possibility of discriminatory practices." ${ }^{\text {, }}$ The Health Insurance Review and Assessment Service ("HIRA") of Korea will review the Policy. Korea has further committed that, during review process, HIRA will work closely with the US and provide meaningful consultation and transparency in making any amendments. ${ }^{36}$

\section{Amendments in the Investor-State Dispute Settlement}

The revision of KORUS FTA was initiated at the behest of the US. During the negotiation, however, Korea had the prime interests in revisiting investor-state

32 PhRMA Statement on Korea-US Trade Agreement, PhARMA website, Feb. 21, 2012, available at https://www.phrma. org/press-release/phrma-statement-on-certification-of-korea-u-s-free-trade-agreement (last visited on Apr. 2, 2019).

33 USTR, Letters of Exchange between Robert Rapson, Deputy Chief of Mission, US Embassy in Seoul and Seung Tak Kim, President of Health Insurance Review Assessment Service (Mar. 2018), available at https://ustr.gov/about-us/ policy-offices/press-office/fact-sheets/2018/march/new-us-trade-policy-and-national (last visited on Mar. 31. 2019).

34 Supra note 26.

35 Drugs from US Likely to be More Expensive after FTA Deal, Joong Ang ILBo DAILY, Mar. 31, 2018, available at http:// koreajoongangdaily.joins.com/news/article/article.aspx?aid=3046309 (last visited on Apr. 2, 2019).

36 Supra note 33. HIRA was expected to complete necessary amendments by December 31, 2018. As of April 2019, however, the new version of the Policy was not available to the author. 
dispute settlement ("ISDS"). ${ }^{37}$ Considering the recent love and hate relationship with ISDS around the world, some on-going negotiations of new FTAs, to which either the US or Korea or both are parties as well as discussions on possible reforms in the UNCITRAL, created some interests in the revision of KORUS FTA to see what innovation it may bring in the ISDS. ${ }^{38}$ Moreover, considering the US withdrawal from TPP and re-negotiation of NAFTA which includes phasing out of ISDS, it was natural to observe how the US deals with the ISDS in the revised KORUS FTA. ${ }^{39}$ Whatever changes that came in the revised KORUS FTA, were neither new, nor unexpected. Although there could have been some progress or innovation, that was not taken up by the US or Korea.

At the time of negotiation of the original KORUS FTA, there was a huge public protest in Korea against including ISDS in KORUS FTA. The Korean people came out protesting against KORUS FTA in general and ISDS. ${ }^{40}$ Even the Korean courts became involved in deciding legal challenges relating to inclusion of ISDS in KORUS FTA. ${ }^{41}$ Against this backdrop, Korea's interests on renegotiating ISDS during the revision of KORUS FTA was intriguing to say the least.

The first major change in the ISDS has recognised the government's legitimate welfare objectives based on how an investor or an investment may be treated differently without violating national treatment or most favoured nation treatment. The revised KORUS FTA clarifies that whether a treatment is accorded in 'like circumstances' dependent upon the totality of the circumstances including legitimate welfare objectives of the government. ${ }^{42}$ In other words, in 'like circumstances' foreign

37 Supra note 26.

38 For example, some countries (e.g., India) have taken decision to withdraw from ISDS. At the same time, AustraliaHong Kong FTA has included ISDS provisions. Korea is a party to RCEP negotiation which is considering including ISDS. The UNCITRAL Working Group III is now discussing possible reforms in ISDS.

39 USTR, The United States Officially Withdraws from the Trans-Pacific Partnership (Jan. 2017), available at https://ustr. gov/about-us/policy-offices/press-office/press-releases/2017/january/US-Withdraws-From-TPP; Agreement between the United States of America, the United Mexican States, and Canada Text, Nov. 30, 2018, available at https:/ustr.gov/ trade-agreements/free-trade-agreements/united-states-mexico-canada-agreement/agreement-between (all last visited on Apr. 7, 2019).

40 The Mass People's Resistance against KorUS FTA has Started, Europe-Solidaire website, Nov. 29, 2006, available at http://www.europe-solidaire.org/spip.php?article4179 (last visited on Apr. 7, 2019).

41 Review Opinion on the Investor-State Dispute Resolution Procedure under the Korea-US Free Trade Agreement (Jan.12, 2007), National Court Administration [The Supreme Court], available at http://bilaterals.org/?korean-supremecourt-opposing-isds\&lang=es. In 2012, the Supreme Court of Korea opined to renegotiate ISDS clause in KORUS FTA. See Eun-joo Jung, Supreme Court Recommends Renegotiation of ISD Clause, Hanyoreh DaILy, Apr. 26, 2012, available at https://www.bilaterals.org/?supreme-court-recommends (last visited on Apr. 7, 2019).

42 Protocol Between The Government of The Republic of Korea and The Government of The United States of America Amending The Free Trade Agreement Between the United States of America and the Republic of Korea (Mar. 2018), ๆ 4(a), available at https:/ustr.gov/about-us/policy-offices/press-office/fact-sheets/2018/march/new-us-trade-policy-and- 
and local investors or investments may be treated differently to satisfy legitimate public welfare objectives of the host government. Government's regulatory space and power have been further fortified by clarifying that, for the purpose of minimum standard of treatment in Article 11.5, "the mere fact that a Party takes or fails to take an action that may be inconsistent with an investor's expectations does not constitute a breach of this Article (minimum standard), even if there is loss or damage to the covered investment as a result." ${ }^{\prime 3}$ This amendment limits investors' claim based on fair and equitable treatment ("FET") and gives some space to governments to pursue welfare related policies for the benefit of the local population. Moreover, the scope standard of treatment has always been contentious in ISDS.

Therefore, Article 11.5 of the original version of KORUS FTA referred to all customary international law principles that protect the economic rights and interests of aliens. ${ }^{44}$ The burden is on the investor with regards to the FET claims to prove all elements of its claims consistent with general principles of international arbitration law. ${ }^{45}$ Though an investor needs to prove appropriate causal link between the government's action and loss suffered by the investor, if the government action is taken for the purpose of realising the legitimate welfare policy of the host government, then the likelihood is that the government action will be considered justified. Furthermore, the revised KORUS FTA allows the arbitral tribunal to dismiss a claim which is "manifestly without legal merit" as a preliminary question. ${ }^{46}$ This will help eliminate frivolous claims and also deter the filing of frivolous claims.

Like any other government, for the Korean government's action based on legitimate welfare objectives needed protection from ISDS claim. There are two ISDS claims against Korea which are ongoing under the original KORUS FTA. They arose out of the government approved merger between two Samsung Group affiliates Samsung C\&T and Cheil Industries in 2015. In one ISDS case, an investor who owns 7 percent stake in Samsung C\&T is claiming USD 770 million in compensation for the loss of the value of his share due to unfair merger terms which was mediated and approved by the Korean government run National Pension Service. They had substantial shareholder votes in Samsung C\&T. ${ }^{47}$ The other ISDS claim is based on the

national (last visited on Apr. 7, 2019).

$43 \quad I d .$, ๆ 4(d). [Emphasis added]

44 USTR, The Free Trade Agreement between the United States of America and the Republic of Korea, annex 11-A (June 30, 2007), available at https://ustr.gov/trade-agreements/free-trade-agreements/korus-fta/final-text (last visited on Apr. 7, 2019).

45 Supra note $42, \boldsymbol{\Upsilon} 4(\mathrm{j})$.

46 Id. $94(1)$.

47 Elliot Associates L.P. v. Republic of Korea (PCA Case No. 2018-51), available at https://www.italaw.com/cases/6856 
same cause of action, i.e., Samsung merger with Cheil, but in that case a New York based hedge fund Mason Capital Management is claiming USD 175million. ${ }^{48}$ Mason asserts: "Korean government officials, from the highest level, through to the NPS, an organ of the State, acted to manipulate the vote motivated by bribery, favouritism to the Lee Family, and open hostility toward non-Korean investors." ${ }^{49}$ This merger deal was one of the reasons for the impeachment of the former President Park Geun-hye and arrest of Samsung Group heir Jay Yong Lee. ${ }^{50}$

These two cases also show that the same cause of action-merger of Samsung Group affiliates has been used by the two investors which is nothing but an example of multiple claims by multiple parties based on the same facts. As a matter of judicial efficiency, these two claims could be combined and dealt with together to save public money. ${ }^{51}$ In order to address multiple claims the amendment in the revised KORUS FTA has restricted multi- national companies to raise the ISDS claim under KORUS FTA if the issue has been dealt with through trade agreements with countries or parties such as the Korea-EU deal. ${ }^{52}$ More specifically, the revised KORUS FTA says:

An investor of a Party may not initiate or continue a claim ... if a claim involving the same measure or measures alleged to constitute a breach ... and arising from the same events or circumstances is initiated or continued pursuant to an agreement between the respondent and a non-Party by: (i) a person of a non-Party that owns or controls, directly or indirectly, the investor of a Party; or (ii) a person of a non-Party that is owned or controlled, directly or indirectly, by the investor of a Party. ${ }^{53}$

In order to qualify as an "investor of a non-Party" and "investor of a Party" a mere attempt to make an investment is not sufficient. In addition, such attempt to an investment should include concrete action or actions to make investment. This includes channelling resources or capital in order to set up a business or applying

(last visited on Apr. 9, 2019).

48 Mason Capital L.P. and Mason Management LLC v. Republic of Korea (PCA Case No. 2018-55), available at https:// www.italaw.com/cases/6854 (last visited on Apr. 9, 2019).

49 US Fund Claims \$175 million from South Korea over Samsung units' 2015 Merger, Bus. Insider, July 3, 2018, available at https://www.bilaterals.org/?us-fund-claims-175-million-from (last visited on Apr. 9, 2019).

50 Id.

51 Ji-hye Shin, Revised FTA to Curb Overuse of Legal Dispute by Foreign Investors, Korea Herald, Sept. 4, 2018, available at http://bilaterals.org/?revised-fta-to-curb-overuse-of (last visited on Apr. 9, 2019).

52 Sung-hyun Lim \& Eun-joo Lee, Revised Korea-US FTA goes into effect on Jan. 1, PulSE, Jan.1, 2019, available at https://www.bilaterals.org/?revised-korea-us-fta-goes-into (last visited on Apr. 9, 2019).

53 Supra note $42, \boldsymbol{\Upsilon} 4(\mathrm{i})$. 
for a permit or license. ${ }^{54}$ This amendment is particularly helpful in the situations where multinational or group of companies initiate ISDS indirectly through their subsidiaries on the same facts and circumstances. However, the claim may proceed only with the consent of respondent State if that agrees to continue with the claim or if investor of a Party agree to consolidate those claims. ${ }^{55}$ Consolidation of claims, if possible, will be helpful in reducing costs and time associated with ISDS claims. Excessive use of ISDS in KORUS FTA was one of the concerns of the Korean government which to some extant has been addressed in the revised KORUS FTA. However, some may still argue that total abolishing of ISDS from KORUS FTA would have been a better solution. ${ }^{56}$

In the context of ISDS, the revised KORUS FTA has made one expected change with regards to application of MFN on dispute settlement mechanism. Ever since the Maffezini case decided to apply MFN on dispute settlement, chaos has been created within the ISDS community. ${ }^{57}$ Many years have passed, but there is still no consistent jurisprudence yet with regards to the application of MFN on dispute settlement mechanism. Investment cases dealing with this issue have given conflicting rulings leading to almost half of those cases. They have supported application of MFN on dispute settlement. The other half has rejected that proposition. One way to resolve this issue is to put further clarification in the text to explain whether the application of MFN is to be restricted and not applicable on dispute settlement mechanism. The revised KORUS FTA has taken this approach. It explicitly stated: "For greater certainty, the treatment referred to in this Article (i.e., Most-Favoured-Nation Treatment) does not encompass international dispute resolution procedures or mechanisms, such as those included in Section B (Investor-State Dispute Settlement). ${ }^{, 58}$ It is hoped that neither investor will make such claims under the revised KORUS FTA; nor tribunal will apply MFN on dispute settlement mechanism. However, as such an amendment may not be applicable in retrospect, claims already initiated against Korea may still have to deal with this issue. Therefore, one can only hope that the concerned arbitral tribunal will show restraint in applying MFN on dispute settlement mechanism.

A new Joint Committee has been created for the purpose of initiating discussion

54 Id. $9(\mathrm{n})$.

55 Id. $₫ 4(\mathrm{i})$.

56 Supra note 51.

57 Emilio Augustine Maffezini v. The Kingdom of Spain (ICSID Case No. ARB/97/7), available at https://www.italaw. com/cases/641 (last visited on Apr. 7, 2019).

58 Supra note $42, \uparrow 4(\mathrm{c})$. 
regarding operation of the investment Chapter including any potential improvements. ${ }^{59}$ This Committee will ensure that the investment Chapter continues to meet the objectives of the Parties. In this regard the Committee will work to providing meaningful procedures for resolving investment disputes and effective mechanisms in order to eliminate frivolous claims and deter the filing of frivolous claims. This will be in line with the arbitral tribunal power to reject claims without manifestly legal merit and a preliminary question. Moreover, in the future whenever an investment arbitration tribunal will interpret or apply a provision of ISDS in KORUS FTA in an investment case which may go against the original intention of the US and Korea with regards to that provision, the Joint Committee may exercise its power (i.e. to ensure that the investment Chapter continues to meet the objectives of the Parties) to reject the award given by the arbitral tribunal.

Whilst the revised KORUS FTA has made improvements in the exiting ISDS, it has also lost an opportunity to consider establishing a bilateral appellate mechanism for investment cases. In the original version of KORUS, the US and Korea agreed to come back after three years and consider whether to establish a bilateral appellate body to review awards rendered by arbitration tribunal. ${ }^{60}$ There have been some initiatives taken elsewhere to include appellate body for the investment disputes or an investment court. This should have been appropriate for Korea to initiate such discussions with the US in the course of revising KORUS FTA. ${ }^{61}$

\section{Conclusion}

The Trump administration, at the start of its term, was going on a rampage against FTAs one of which was KORUS FTA. There was a time when the US was considering withdrawing from KORUS FTA altogether unless its demands were met. One of those major demands included giving greater access to American automobiles in the Korean market. Though Korean automakers have not yet started exporting Korean made trucks, the US wanted to continue imposing tariffs on the Korean trucks. American pharmaceutical companies wanted to get non-discriminatory treatment

59 Id. $\uparrow 4(\mathrm{p})$.

60 Supra note 44, annex 11-D.

61 EU-Vietnam FTA has included appeal system in investment arbitration. See Koushan Das, Investment Protection in EU Vietnam FTA, ISDS Platform: Vietnam Briefing (Aug. 24, 2018), available at https://isds.bilaterals.org/?investmentprotection-in-eu (last visited on Apr. 9, 2019). 
in Korea particularly for price fixation. In general, American exporters wanted consistent and transparent application of rules by customs authorities of Korea. Those demands were made with the view to protecting the US companies, nevertheless Korea agreed to meet those demands of the US in the revised KORUS FTA. From that perspective, the revision of KORUS FTA is an example of successful negotiation for the US. From Korea's perspective also, the revision of KORUS FTA has met Korean's interests such as the review of ISDS particularly ensuring regulatory space for both governments in pursuing their legitimate welfare policies. Additionally, Korea also secured exemption from the US new 25 percent tariff on steel. Even for the purpose of commencing denuclearization negotiation between the US and North Korea, the revised KORUS FTA played a 'significant' and 'very important' role, because it set up a successful precedent of revising FTAs with other countries. ${ }^{62}$ Thus, the revision of KORUS FTA has not only achieved its commercial purpose, but also has paved the way for creating political peace in Korean peninsula.

62 Supra note 2. See also Jane Chung \& Christine Kim, How Seoul Raced to Conclude U.S. Trade Deal Ahead of Korea Denuclearisation Summit, JAPAN TIMES, Mar. 30, 2018, available at https://www.japantimes.co.jp/news/2018/03/30/ asia-pacific/politics-diplomacy-asia-pacific/seoul-raced-conclude-u-s-trade-deal-ahead-north-korea-denuclearizationsummit/\#.XM_yuLZ7Fo4 (last visited on May 5, 2019). 